\title{
New climate change information modifies frames and decisions of decision makers: an exploratory study in forest planning
}

\author{
Michal Petr ${ }^{1,2}$ - L. G. J. Boerboom ${ }^{1} \cdot{\text { Duncan } \text { Ray }^{2} \cdot \text { Anne van der Veen }}^{1}$
}

Received: 23 June 2014/ Accepted: 7 June 2015/Published online: 24 July 2015

(C) The Author(s) 2015. This article is published with open access at Springerlink.com

\begin{abstract}
Information helps decision makers to address and to decide about environmental problems. In the context of climate change adaptation, often knowledge is missing on how the available information from impact models affects the decision-making process. The main aim of this study was to explore the extent of ambiguity and how new climate change information influenced decision of forest planners. We investigated changes in decisions of planners about forestry actions representing species choice and forest tourism and expiry dates of these actions leading to environmental constraints in the provision of ecosystem services. Forest planners evaluated expiry dates using four forest ecosystem services: forest production, stand yield class, sequestered carbon, and potential tourism. Data were collected during workshops with eleven forest planners from three forest districts in Scotland. Presented climate
\end{abstract}

\section{Editor: Elena Bennett.}

Electronic supplementary material The online version of this article (doi:10.1007/s10113-015-0827-9) contains supplementary material, which is available to authorized users.

Michal Petr

Michal.Petr@forestry.gsi.gov.uk

L. G. J. Boerboom

1.g.j.boerboom@utwente.nl

Duncan Ray

Duncan.Ray@forestry.gsi.gov.uk

Anne van der Veen

A.vanderVeen@utwente.nl

1 Faculty of Geo-Information Science and Earth Observation (ITC), University of Twente, Enschede, The Netherlands

2 Forest Research, Forestry Commission, Northern Research Station, Roslin EH25 9SY, UK change information modified the understanding and frames of planners about forestry actions assessed with accompanying expiry dates. Changes in the frames of planners often result in both earlier and later expiry dates. Ambiguity of planners was found to be dependent on diversity in frames and difficulty in evaluating multiple ecosystem services. These findings imply that due to ambiguity forest planners might find it hard to choose climate change adaptation measures and researchers can struggle to convince planners with new research findings.

Keywords Uncertainty · Ambiguity · Framing · Decision-making · Information · Climate change adaptation

\section{Introduction}

Climate change will have an impact on both socio-economic and environmental systems, but whether or not, and how exactly, society should adapt is still a discussion in many public and research debates (Adger et al. 2009; IPCC 2007, 2014). Knowledge about climate change impacts on different types of ecosystem is available from many studies at global and regional scales (Bateman et al. 2013; Fischlin et al. 2007; Schröter et al. 2005). However, uncertainty remains about climate change impacts due to the natural variability of a climate system and due to our lack of knowledge about its natural processes. Climate change uncertainty also influences the decision makers' perceptions of climate change-related risks, as was the case for forest planners (Petr et al. 2014a). Decision makers managing ecosystems, such as forests, will have to decide which suitable climate change adaptation measures to apply (Lindner et al. 2010). The factors influencing their 
decisions in applying adaptation measures are, for example, climate change risk perceptions (Etkin and Ho 2007; Petr et al. 2014a), beliefs about climate change (Blennow and Persson 2009), and the framing of climate change as a problem (Dewulf 2013; Morton et al. 2011). But knowledge is still missing on how does new climate change information modifies a decision maker's understanding and a decision about delivery of ecosystem services.

Information about future climate change impacts presented to decision makers should support their decisionmaking and help them to adapt to potential adverse impacts. Climate change adaptation aims to reduce potential future impacts (Jones et al. 2012). However, in applying adaptation measures decision makers should try to avoid maladaptation-a situation when applied adaptation measures make the system more vulnerable (Barnett and O'Neill 2010). Crucial aspects of adaptation are the view of decision makers on climate change, as represented by their "frames" and how they define problems related to climate change. By frames, we mean an interpretation of reality or a problem (Brugnach et al. 2008). In addition, if decision makers have multiple frames about reality, then ambiguity as uncertainty will occur (Dewulf et al. 2005). We understand uncertainty as an incomplete knowledge about a phenomena or a problem, while ambiguity represents a specific source of uncertainty focusing on contrasting or diverse interpretation of a problem among decision makers. The analysis of people's frames and framing has many benefits; for example, it helps to better understand how people make decisions (Tversky and Kahneman 1981), to find differences of decision makers understanding of a problem (Brugnach et al. 2008), and to understand the information used to address a problem and whether a problem exists (Dewulf 2013). Additionally, a problem, such as use of land in a national park, can be framed in multiple ways and consequently will result in diverse perspectives with different solutions (Dewulf et al. 2005). We can illustrate the concept of framing, for example, through the case of a pest killing a tree, with one frame highlighting the high vulnerability of the tree to pest attack, the other stressing the high capability of pests to kill the tree, and another considering it part of the natural system.

All aspects of framing also apply to the climate change adaptation discourse and climate change risk communication. A study by Dewulf (2013) concluded that for climate change adaptation it is important to understand a problem and frames influenced by gathered and used information. Types of information presented to a decision maker will influence his/her frames resulting in different understandings of a problem and possibly in taking different actions. Nevertheless, knowledge is lacking about whether frames can delay adaptation actions (Dewulf 2013). Previous studies investigated mainly what frames decision makers have about a decision problem (Dewulf et al. 2005) and about climate change (Morton et al. 2011). Still, empirical knowledge is missing on whether new information will change (and how) the decision makers' frames for a particular climate change problem. An understanding of frames is important for the clear communication between research and decision makers, particularly when viewing researchers as information providers. Therefore, this research is situated within the broader literature on climate change risk communication (Pidgeon and Fischhoff 2011), which also addresses risk understanding, values at stake, and emotions. We focus on how information can change attitudes and the willingness of people to adapt to climate change (Moser and Ekstrom 2010), especially in the understanding stage. Specifically, by analysing framing, we investigate problem definitions and the urgency to act.

Forest planners have their own views and interpretations of forests and their objectives. Planners are aware of the multiple ecosystem services forests provide to people that often define forestry objectives (Forestry Commission Scotland 2013). But the question remains around how planners understand inherent climate change uncertainty? The previous research on forest planning in Britain showed that planners believe in a high degree of controllability of drought impacts with forest management and they also indicated active uncertainty management associated with forest models (Petr et al. 2014a). This observation confirms the frames of planners about drought and an acknowledgement of the limits of forest models. Therefore, they should be keen to actively look for information offered from models and keen to adapt to drought and climate change. However, the way in which planners frame a problem can change due to new information, which the research community can provide. For example, a study of natural resource management in Ecuador by Dewulf et al. (2005) showed diverse understanding of problems among stakeholders stimulated with different information leading to changes in stakeholder frames. Similarly, in developing plans, forest planners use a range of information sources about multiple forest services and consider diverse demands from stakeholder and the public. Therefore, the conflict of interests among stakeholders about the best use of forests can be a reason of ambiguity and the uncertainty of planners. Ambiguity then represents a diverse interpretation of information and conflicts over forest use. For climate change adaptation in forest planning, we have to understand the frames of forest planners for forestry management actions providing the main ecosystem services. Also we need to understand decisions of planners about the urgency of these actions. Analysis of how planners frame these problems offers a better understanding of the reasons leading to planning decisions and explains the planners' willingness to adapt to climate change. 
This study explores whether new information about drought and climate change will modify the frames of forest planners. Our case study focuses on the National Forest Estate management and planning in Scotland. We investigated changes in the frames of planners on forestry actions with planners specifying their expiry dates, representing the time period at which forest stands stop providing the required amount of ecosystem services. The concept of expiry dates as limits is not new to forest planners because they already set their own constraints to different forestry actions in their day-to-day decisions, such as limits for tree growth and knowledge of the maximum mean annual increment for a species on a site. Forestry actions describe the forest management activities initiated by planners as part of the planning process. Consequently, the two research questions for this study are: (1) at which decade in the future do forest planners believe climate change impacts will become serious, and (2) will planners change their initial frames about forestry actions suitable for climate change adaptation when confronted with new climate change information. To answer these questions, we used information from drought and climate change impact assessments on four ecosystem services in three districts. These show impacts for two possible threshold values for eight forestry management actions in an action expiration map. Our threshold values were specific for each of the three investigated forest districts. Then, using information from the action expiration maps in workshops we explored how forest planners decide about forestry actions with and without climate change information.

We structured this study as follows. First, we describe the workshops in which we studied changes in forest planning decisions without and with new climate change information and how we analysed the data. Next section presents results for changes in the frames of forest planners due to their understanding of different expiry dates of forestry actions based on new climate change information. The final section discusses the findings in a wider climate change adaptation context related to forest planning and management and concludes with a summary of the study.

\section{Materials and methods}

\section{Data collection}

\section{Workshop design and input data}

To explore how forest planners decide about forestry actions without and with new climate change information, we used a workshop setting. The workshop has proved a suitable method in similar studies, for example, in exploring preferences of stakeholders about coastal management (Tompkins et al. 2008) and investigating expert judgments of alternatives for forest management (McDaniels et al. 2012). The strength of our design was to explore how planners define expiry dates for the same forestry management actions first without and then with presented climate change information. We could thus investigate whether new climate change information would stimulate change in the frames of planners and how their decisions change under ambiguity and climate change. Additionally, the workshops helped us to interact with planners. Two main limitations of the workshops were required time-consuming preparation, and the small number of forest planners involved.

Information for the workshops consisted of eight predefined forestry actions incorporated into an action expiration map for the planning mechanisms in each of the three studied forest districts. We defined forestry actions important for forest management with evaluations based on tree species covering more than $50 \%$ of the public estate, for which we had quantified climate change impacts on ecosystem services, and we also included tourism. Furthermore, we used four quantified ecosystem services available for this study to give a more comprehensive view on forest-related problems. To assess the impacts of climate change on ecosystem services at high spatial and temporal resolution, we used information from the latest climate change projections for the UK (Murphy et al. 2009). Our forestry actions-evaluated with four ecosystem services-relate to two groups: a) investment in keeping the current species while applying the same forest management and b) investment in potential forest tourism to improve forest facilities (details in Online Resource Fig. S1). Additionally, we split the actions into the lowlands and uplands as described in Petr et al. (2014b) because of different tree growth rates. A final list of actions in a group "investment in current species" included six actions split by three major species to "keep spruce", "keep pine", and "keep oak" and classified by lowlands and uplands. Finally, a group of "potential forest tourism" included two actions of "adjustment of forest facilities" and was classified by lowlands and uplands. The forestry actions were assessed for four forest ecosystem services: the traditional provisioning services of forest production; mean stand yield class; the regulating service of sequestered carbon; and a new cultural service of tourism potential. These services were assessed for drought and climate change impacts projected over the next 80 years and described in the Online Resource.

We structured the workshop into five steps with five tasks, with tasks mainly consisted of writing down expiry dates for forestry actions at a decade level and a rationale for their decision (details in Online Resource Table S2). The first step investigates the planners own list of forestry 
management actions relating to drought with their task to free list actions and specify their future expiry dates. The second step explores how planners define expiry dates to pre-defined forestry actions without any provided climate information with their task to define future expiry dates. In the third step, we presented to the planners the likely drought and climate change impacts on forests and described step-by-step the development of action expiration maps. There was no task for planners in this step. The fourth step investigates planners' decisions about pre-defined forestry actions, but this time with new information about drought and climate change impacts shown in action expiration maps. Tasks of planners were to individually define future expiry dates for actions for one of the three emission scenarios. In the final step, planners evaluated the practicality of the presented information for forest planning using a 7-point Likert scale. Each step consisted of one or two simple tasks, which took about $15 \mathrm{~min}$ each, and a group discussion that lasted between 45 and $60 \mathrm{~min}$. We pre-tested the workshop within our research group before running the workshops with the planners.

\section{Study area}

We approached planning teams in three Scottish forest districts managing the National Forest Estate, with each district having different estimated future drought impacts on key forest ecosystem services. This allowed us to understand diverse opinions about drought and climate change impacts across Scotland. We chose Moray and Aberdeenshire (Moray), Dumfries and Borders (Dumfries), and Galloway forest districts as study areas because drought is expected to have a large impact on forests and on the provision of ecosystem goods and services. Table S1 in Online Resource presents information about species composition in each district, and Fig. S2 in Online Resource shows the extent of the forest area in each district. For each district, we ran either a full-day or a half-day workshop with the planning team in January 2014. About a third of all Forestry Commission Scotland planners took part in the workshops with five planners in Moray and Aberdeenshire, three planners in Dumfries and Borders, and three planners in Galloway. All workshops were held in the district offices, which provided a familiar environment for planners.

\section{Data analysis}

We conducted data and text analysis of the planners' responses to identify how they decide about expiry dates for forestry actions both without and with the climate change information. We organised and coded all written responses by tasks and by forest district into a spreadsheet.
Then, we coded (Babbie 2010) all forestry actions from the free-listing task into the following groups: require information, other actions, species choice, site preparation, and silviculture practice. Next, we decoded unclear responses for expiry dates of forestry actions to specific decades, such as "the rest of the century" was decoded to 2100. Also, when the responses were unavailable or unclear, we used text in a rationale-specified by the planners-to define expiry dates for actions. Having coded forestry actions, we calculated absolute frequencies for actions by expiry dates into decades. These frequencies were compared with responses before and after we presented to them the climate information in the action expiration maps. Finally, we evaluated how helpful the information from the adaptive pathways approach in action expiration maps was for planning practice and how easy it was for the planners to define expiry dates for forestry actions on a 7-point Likert scale (from 1 very helpful to 7 very unhelpful, and DN for don't know). We performed all the analyses in $\mathrm{R} 2.14 .2$ statistical software (R Development Core Team 2012) with plyr 1.8 package (Wickham 2011) and used the lattice 0.20-10 package for visualisation (Sarkar 2008).

\section{Results}

We present results in five sections structured by the sequential five tasks of the workshops with one additional section for comparing results. First, we provide a summary of the free listing of forestry management actions relevant to forest planning. Next, we summarise responses indicating expiry dates of forestry actions first without any climate change information and then with the provided climate change information. Then, we highlight differences of planners in understanding of forestry actions and their expiry dates due to new climate change information. Finally, we evaluate the usability of the new climate change information for forest planning.

\section{Free listing of forestry management actions}

Without any prior information about climate change and drought, the forest planners had to free list forestry actions they considered drought sensitive and relevant to their district. Additionally, they had to define expiry dates for these actions and provide a rationale for their choice. In the Moray district - with a relatively dry climate and with the highest potential drought impacts-the planners indicated 13 actions (46\% of all actions) would reach their expiry dates in the 2050s, as shown in Fig. 1. The planners identified the site preparation and silviculture practice as the dominant actions in the 2050s. Still, the planners were unable to define expiry dates for seven actions ( $25 \%$ of all 


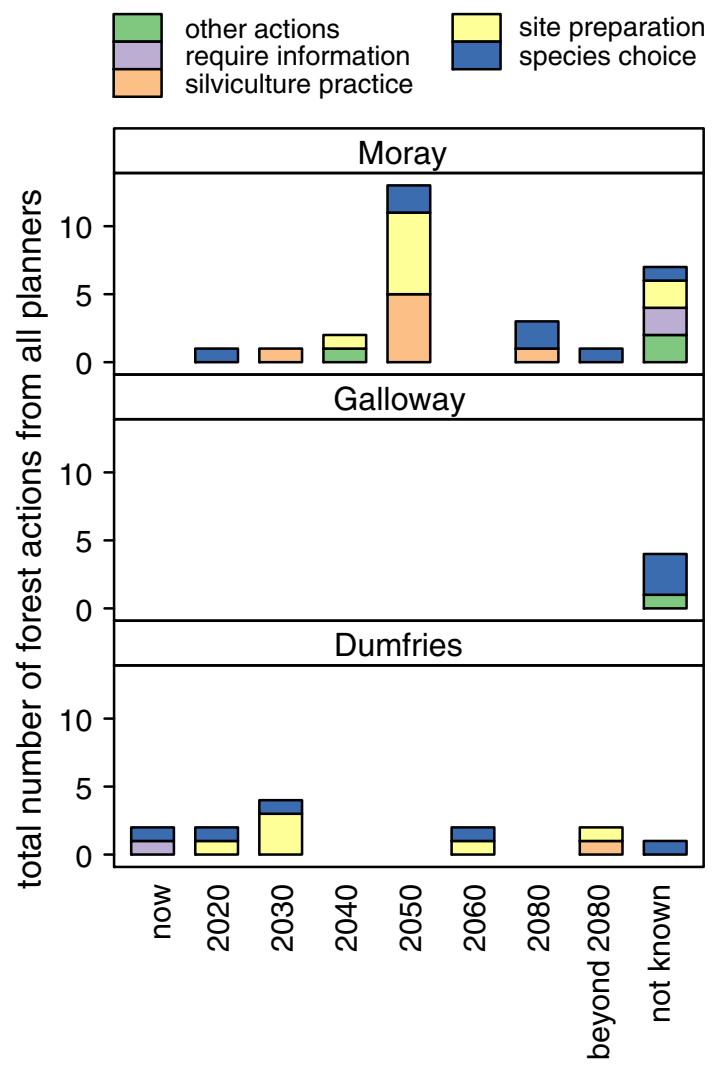

Fig. 1 Frequency of free-listed forestry actions and their expiry dates in the future in three forest districts in Scotland (planners: Moray $n=5$, Galloway $n=3$, and Dumfries $n=3$ )

actions). On the other hand, in the Galloway district—with a relatively wetter climate-planners indicated that no expiry dates would exist for four forestry actions relating to drought, with species choice representing the main forestry action. In the Dumfries district-with a relatively wet climate in the west and a drier climate in the east-the planners indicated eight forestry actions (60\% of all actions) would reach their expiry dates by the 2030s. These planners identified expiry dates for the action of species choice in the majority of time periods. From all forestry actions, the planners recognised the actions of site preparation and species choice as the most frequent and also the most sensitive to drought impacts, hence important for the future forest planning.

\section{Expiry dates for pre-defined forestry actions without climate change impacts' information}

Next, we asked the individual planners to define expiry dates for eight pre-defined forestry actions and to provide a rationale for their choice. The results show summarised responses from all planners in a district, with the maximum number of actions dependent on the number of planners. Having a fixed and meaningful list of actions, the planners were able to define future expiry dates for forestry actions, except for two forestry actions in the Moray district (see Fig. 2a). In Moray, the planners identified 10 forestry actions ( $25 \%$ of all actions) that would reach their expiry dates by the 2050s, while five actions $(12.5 \%$ of all actions) have no future expiry date. In Galloway, the planners indicated no expiry dates for any of the forestry actions, the same responses as their own list of actions in the previous task. In Dumfries, the planners identified 11 forestry actions ( $45 \%$ of all actions) that would reach their expiry dates by the 2050s and six forestry actions ( $25 \%$ of all actions) would have no expiry dates in the future. The results show that in Dumfries the relative number of forestry actions until the 2050s is two times higher than in Moray.

\section{Expiry dates for pre-defined forestry actions with climate change impacts' information}

After providing new information about drought and climate change impacts through action expiration maps, we asked the planners again to evaluate and define individually the future expiry dates for the same eight forestry actions. This time we randomly assigned action map with drought impacts for one of the three emission scenarios to each planner to minimise any anchoring effect (Tversky and Kahneman 1974). In Moray, the planners indicated that 14 forestry actions (35\% of all actions) would reach their expiry dates by the 2050s and only three actions ( $7.5 \%$ of all actions) would have no future expiry dates (see Fig. 2b). However, the planners were unable to decide about expiry dates for 16 forestry actions (40\% of all actions) - representing responses for "not known" category. In Galloway, the responses of planners show four forestry actions (16\% of all actions) that would reach their expiry dates by the 2050s, but still the largest proportion of actions equals to 12 (50\% of all actions) without any future expiry dates. One undecided planner was the reason for the high number of "NA" responses. In Dumfries, the planners believed that ten forestry actions (41\% of all actions) would reach their expiry dates by the 2050s, but nine forestry actions (37.5\% of all actions) would have no expiry dates in the future. In all districts, forestry actions in the lowlands-drier and warmer areas-would have their expiry dates mostly in the first half of the twenty-first century, whereas the majority of actions in the uplands would show either no expiry dates or unknown expiry dates.

\section{Comparison between expiry dates for forestry actions without and with climate change information}

We compared individual responses of planners for expiry dates of all eight forestry actions first without and then with 
actions in lowlands actions in uplands

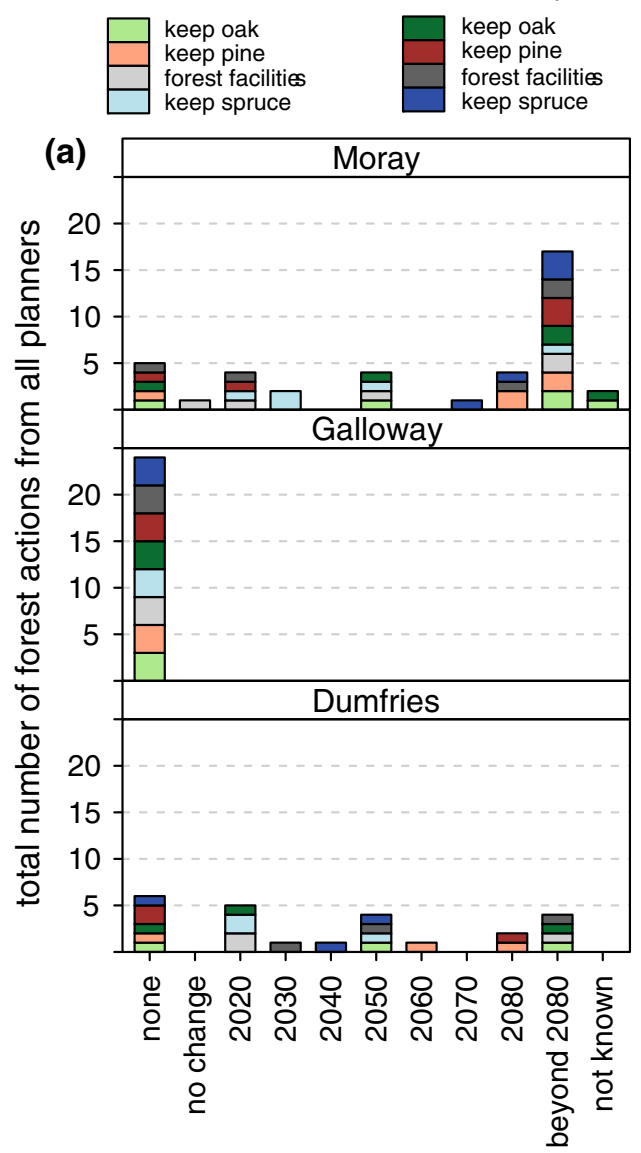

Fig. 2 Frequency for eight pre-defined forestry actions and their expiry dates in the future defined by individual planners a without climate change information and $\mathbf{b}$ with new climate change information.

the information about drought and climate change impacts. Climate change information was always related to a district. In Fig. 3, we see a small shift in expiry dates for forestry actions to earlier decades across three districts after the planners have seen the new climate change information. For example, in Dumfries more forestry actions have their expiry dates from now until the 2030s. Having additional climate information, the planners reduced the amount of forestry actions with no expiry dates (the "none" category) by two actions in Moray and by 12 actions in Galloway. On the other hand, the number of forestry actions with no expiry dates increased by three in Dumfries. If the planners perceived no ambiguity about specifying expiry dates for forestry actions, then we would expect the same expiry dates without and with the new climate change information. However, the results show that ambiguity, as multiple views on a problem, exists as planners changed their decisions about forestry actions. (b)

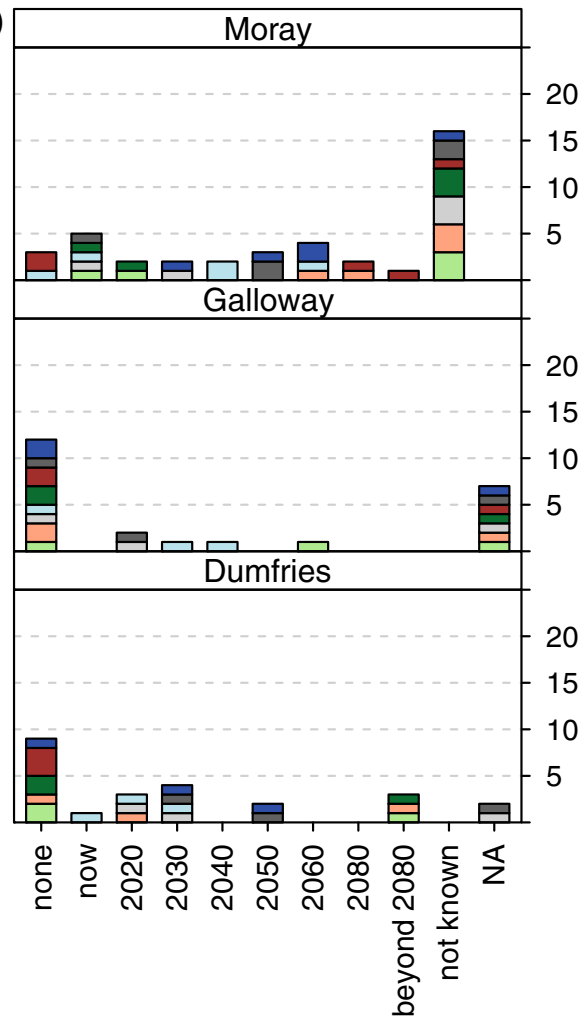

Results for three forest districts in Scotland (planners: Moray $n=5$, Galloway $n=3$, and Dumfries $n=3$ ). Light colours depict actions in the lowlands and darker in the uplands (colour figure online)

\section{Evaluation of new climate information for forest planning}

We asked forest planners in four statements to evaluate the usability and limitations of the presented information in action expiration maps for their forest planning. The planners in Moray and Galloway districts indicated limited usefulness of information in action expiration maps for their forest planning, but in Dumfries they indicated a small uselessness (see Fig. 4). The planners found it harder to define expiry dates for forestry actions with available information for their districts, with the exception in the Galloway where one planner found it easy. Last, the planners in Moray and Galloway indicated that making decisions with two threshold values for a district was slightly easier, but in Dumfries planners were undecided between easy and hard decisions. Overall, the planners in Dumfries found it hard and less easy to use and decide about expiry dates for forestry actions compared with the 


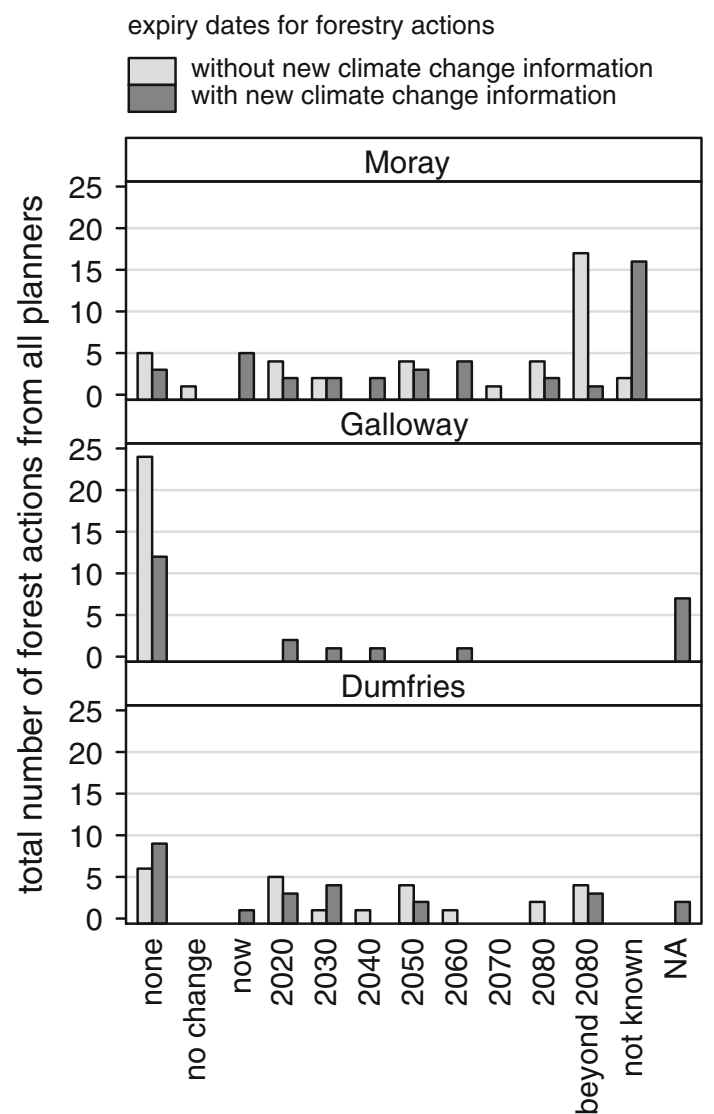

Fig. 3 Changes in expiry dates for forestry actions made by planners before and after drought and climate change information was available for their district

planners in Galloway where it seemed easier for them to decide, and easier to use presented information. Finally, in Moray district the planners were undecided and some believed that presented information in action expiration maps were useful, whereas others thought the information was useless. We received two "Not Available" answers for a statement "decide with two reduction values" in Moray and Dumfries districts.

\section{Discussion and conclusions}

This study of ambiguity in forest planners' decision-making - in the context of climate change adaptation - found changes in frames about expiry dates for forestry actions. These changes were due to the new information resulting in a shift of expiry dates and in alternations of expiry dates. Our findings suggest that planners are capable of making decisions about forestry actions into the future. However, when they were confronted with uncertainty, represented either by too much information about climate change impacts or by having multiple views about forestry actions, they responded with some hesitation and with different

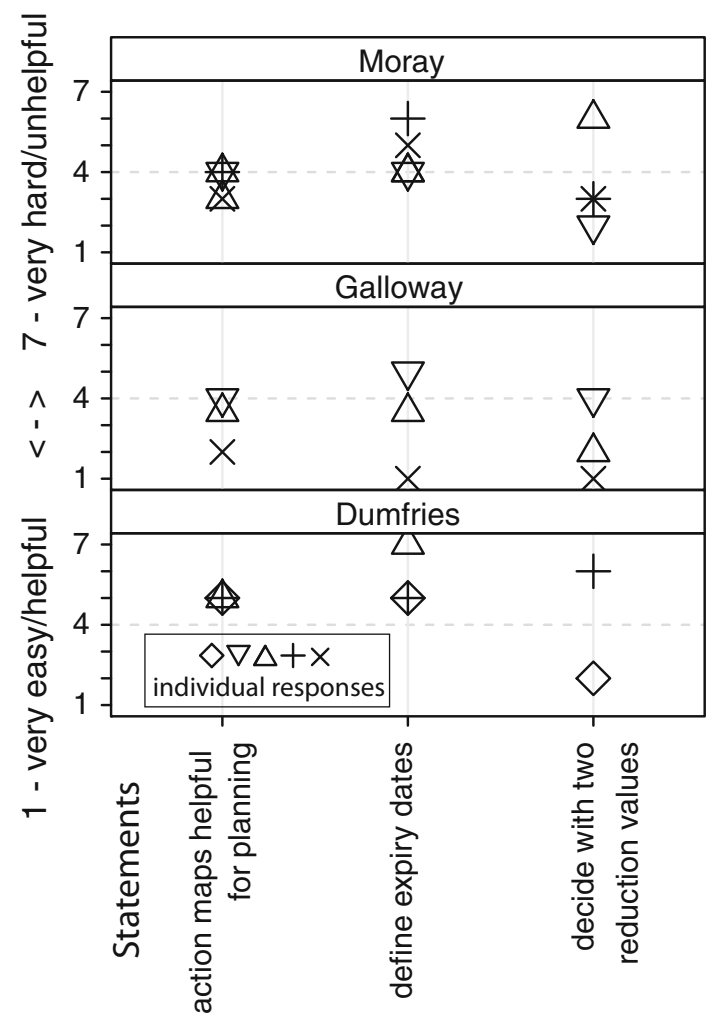

Fig. 4 Evaluation of usability of presented action expiration maps for forest planning with three statements. Symbols represent planner's responses

answers. We now address our two research questions and discuss their broader implications for climate change adaptation and policy development.

With respect to possible expiry dates of forestry actions, we investigated when individual forest planners would start to adapt to climate change, as triggered by the new information presented. Starting with their own list, the planners indicated that between 0 and 13 forestry actions-district specific-would reach their expiry dates by the 2050s. Then, with a pre-defined list of eight forestry actionskeeping spruce, pine, and oak and adjustment of forest facilities in the lowlands and uplands-but without any climate change information, the results show that between 0 and 11 forestry actions would reach their expiry dates by the 2050s. However, with climate change information available to planners they modified expiry dates for the same eight forestry actions resulting in a higher number of actions between 4 and 14 reaching their expiry dates by the 2050s. We assume that reasons for these changes are due to the frames planners hold on climate change impacts influenced by the new information presented, as well as their different interpretations of expiry dates. Another reason can be the planners perceptions of different drought impacts on forest ecosystem services, represented by threshold values, ranging by districts with values set for 
Dumfries (10 and $20 \%$ ), for Galloway (5 and $15 \%$ ), and for Moray (20 and $30 \%$ ). In case the planners would have the same frames and the same understanding of expiry dates, we would expect to see the same expiry dates without and with the climate information presented, which was not the case. Another obstacle to define expiry dates was due to incomplete and too broad information presented about ecosystem services mentioned by the planners during the workshops. However, as Dewulf et al. (2005) have mentioned, decisions always have to be made without a complete knowledge, and hence, we believe it is also the case for forest planners. A reason why planners defined no expiry dates for several forestry actions might be because of their disbelief in climate change with a consequent avoidance of adaptation actions, as was the case for some Swedish forest owners (Blennow and Persson 2009). Also, our investigation of expiry dates for forestry actions might go beyond planners' perception of time. For example, study of Dutch and German forest managers found that foresters think mainly within a 15-year time horizon (Hoogstra and Schanz 2009).

With respect to climate change information, we explored the influence of new information on the decisions of planners about forestry actions. Our results show the influence of new information on individual decisions of planners, such as a shift to earlier expiry dates for forestry actions, and how this caused a higher inability to specify expiry dates for actions. For example, in Moray the planners were unable to define expiry dates for 16 forestry actions compared with 2 actions where no climate information was available, whereas in other districts planners were capable of specifying expiry dates. For no expiry dates, presented climate information resulted in planners identifying between 3 and 12 forestry actions (representing 7.5 and $50 \%$ of all actions, respectively) district dependent. But without any prior climate information, planners identified between 5 and 24 forestry actions. These results suggest that new information helped planners to be more certain about expiry dates of actions. Comparing the decisions of planners without and with the climate change information, we can conclude that planners have different frames about forestry actions. Ambiguity - as multiple frames of a problem-might be a reason why planners indicated different expiry dates for forestry actions. This might be as well a consequence of too much information (Dewulf et al. 2005). Additionally, a study by Eyvindson et al. (2012) has found that the amount of forest information presented changed choices of forest plans among forest science students. The consequences of ambiguity about actions and expiry dates then might influence the choice of planners of taking climate adaptation measures. Forest planners may have negative frames due to a reduction in forest ecosystem services, which might result in risk-taking behaviour, as is known from decision-making research (Tversky and Kahneman 1981). These frames could then cause changes in expiry dates for forestry actions. On the other hand, positive frames about potential tourism benefits may make planners keen to think about investing in forest recreation facilities. Of course new information and the planner's frames are not the only explanation for changes in expiry dates for forestry actions. Other explanations for different frames might be planners' risk perceptions of drought and climate change, as a previous study by Petr et al. (2014a) found diverse climate change risk perceptions among British forest planners.

Communication of climate change impacts and risks relates to values-what is at stake and also how you understand or frame a problem (Pidgeon and Fischhoff 2011). In forest management and planning, this links to values provided by forest ecosystem services. Our results show diverse frames for forestry actions among forest districts because of diverse problem interpretation, different tree species cover in districts, and intangible future climate change impacts on forests. This can be also explained by diverse risk perceptions (Petr et al. 2014a) and by diverse forest values at risk (Blennow et al. 2013). Furthermore, our results contributed to a better understanding of barriers to climate change adaptation in the initial "understanding phase" (Moser and Ekstrom 2010). With new information made available to forest planners, they redefined a problem, in our case drought and climate change impacts to forests, by changing expiry dates for forestry actions. This process involves a reframing of their initial perceptions of drought and climate change impacts on forests in their districts while considering what is at stake. Our findings then provide evidence for the wider climate change communication and adaptation offering insight into frames for a range of forest management options.

Findings from this study can help policy makers, forest planners, and scientists to not only better understand possible barriers but also create new options for addressing climate change adaptation. We think that knowing how planners understand, perceive, frame, and use information about climate change can support timely adaptation by advancing it, or delaying it, at a regional and national level. On the one hand, this empirical study revealed possible barriers to climate change adaptation because a lot of new information was hard for the planners to understand. Another barrier can be the ambiguity caused by the new climate information as compared to planners own understanding and knowledge about climate change impacts. Other studies have shown that ambiguity caused by different views on a problem remains a barrier to decisionmaking in natural resources management (Brugnach et al. 2008) and in climate change adaptation (Moser and Ekstrom 2010). One way to reduce ambiguity and to 
improve the uptake of new information from action expiration maps might be to hold consequent workshops allowing planners to become more familiar with this new information. On the other hand, this study offers opportunities for climate change adaptation and shows how the information has the power to shift adaptation actions over time, which could lead to earlier operational adaptation and a higher uptake of climate adaptation policies.

Based on the reflections of planners after each workshop, a workshop setting was a suitable method to disseminate and introduce new climate change information while offering a chance for planners to ask for clarification where required. Clearly, this study has limits, particularly in presenting a large amount of climate change information, which made it hard for the planners to digest in 1 day. Moreover, our findings are subject to errors due to a small sample size of planners. With the planners, however, we investigated the use of action expiration maps, not presented here, to define adaptation pathways developed by (Haasnoot et al. 2013). We observed that information in adaptation pathways were hard for the planners to understand and to define, and hence, future research should expand on their empirical application.

Overall, this empirical study provided a better understanding about frames, related to the application of new climate change information and its effects on forest planning. Furthermore, it highlighted that ambiguity and different frames exist with respect to expiry dates of forestry actions. Policy makers and scientists should be aware of these different frames caused by new information, but at the same time they should promote an increase in knowledge exchange, leading to an uptake of scientific evidence in forest planning. Diverse frames about expiry dates for forestry actions can both delay or speed up climate change adaptation with applying relevant adaptation measures and also depending on the views and beliefs on climate change by planners. Overall, the evidence in our study suggests that new climate change information can change frames of planners resulting in more timely (earlier and later) implementation of adaptation measures. Finally, the future research should expand or replicate this work to other disciplines or industries to investigate how different types of decision makers react to new climate change information and associated ambiguity.

Acknowledgments We thank the Forestry Commission staff who participated in the workshops and Chris Quine for comments to this manuscript. This research has been sponsored by the ForeStClim project "Transnational Forestry Management Strategies in Response to Regional Climate Change Impacts" in the INTERREG IVB programme in North-West Europe of the European Regional Development Fund (ERDF), Project No. 003A. We are grateful to the editor and a reviewer for their valuable and constructive comments on an earlier version of the manuscript.
Open Access This article is distributed under the terms of the Creative Commons Attribution 4.0 International License (http://creativecommons.org/licenses/by/4.0/), which permits unrestricted use, distribution, and reproduction in any medium, provided you give appropriate credit to the original author(s) and the source, provide a link to the Creative Commons license, and indicate if changes were made.

\section{References}

Adger WN, Dessai S, Goulden M, Hulme M, Lorenzoni I, Nelson DR, Naess LO, Wolf J, Wreford A (2009) Are there social limits to adaptation to climate change? Clim Change 93:335-354. doi:10. 1007/s10584-008-9520-z

Babbie E (2010) The practice of social research, 12th edn. Wadsworth, Belmont

Barnett J, O'Neill S (2010) Maladaptation. Glob Environ Change 20:211-213. doi:10.1016/j.gloenvcha.2009.11.004

Bateman IJ, Harwood AR, Mace GM, Watson RT, Abson DJ, Andrews B, Binner A, Crowe A, Day BH, Dugdale S, Fezzi C, Foden J, Hadley D, Haines-Young R, Hulme M, Kontoleon A, Lovett A, Munday P, Pascual U, Paterson J, Perino G, Sen A, Siriwardena G, van Soest D, Termansen M (2013) Bringing ecosystem services into economic decision-making: land use in the United Kingdom. Science 341:45-50. doi:10.1126/science. 1234379

Blennow K, Persson J (2009) Climate change: motivation for taking measure to adapt. Glob Environ Change 19:100-104. doi:10. 1016/j.gloenvcha.2008.10.003

Blennow K, Persson J, Wallin A, Vareman N, Persson E (2013) Understanding risk in forest ecosystem services: implications for effective risk management, communication and planning. Forestry 87:219-228. doi:10.1093/forestry/cpt032

Brugnach M, Dewulf A, Pahl-Wostl C, Taillieu T (2008) Toward a relational concept of uncertainty: about knowing too little, knowing too differently, and accepting not to know. Ecol Soc 13:16 (Art ID 30)

Dewulf A (2013) Contrasting frames in policy debates on climate change adaptation. Rev. Clim. Chang. 4:321-330. doi:10.1002/ wcc. 227

Dewulf A, Craps M, Bouwen R, Taillieu T, Pahl-Wostl C (2005) Integrated management of natural resources: dealing with ambiguous issues, multiple actors and diverging frames. Water Sci Technol 52:115-124

Etkin D, Ho E (2007) Climate change: perceptions and discourses of risk. J Risk Res 10:623-641. doi:10.1080/13669870701281462

Eyvindson K, Hujala T, Kangas A, Kurttila M (2012) Selecting a forest plan among alternatives: consistency of preferences within decision support frameworks. For Policy Econ 15:114-122. doi:10.1016/j.forpol.2011.09.009

Fischlin A, Midgley G, Price J, Leemans R, Gopal B, Turley C, Rounsevell MDA, Dube O, Tarazona J, Velichko A (2007) Ecosystems, their properties, goods, and services. Climate change 2007: impacts, adaptation and vulnerability. In: Parry M, Canziani O, Palutikof J, van der Linden P, Hanson C (eds) Contribution of Working Group II to the Fourth Assessment Report of the Intergovernmental Panel on Climate Change. Cambridge University Press, Cambridge, pp 211-272

Forestry Commission Scotland (2013) The role of Scotland's National Forest Estate and strategic directions 2013-2016

Haasnoot M, Kwakkel JH, Walker WE, ter Maat J (2013) Dynamic adaptive policy pathways: a method for crafting robust decisions 
for a deeply uncertain world. Glob Environ Change 23:485-498. doi:10.1016/j.gloenvcha.2012.12.006

Hoogstra M, Schanz H (2009) Future orientation and planning in forestry: a comparison of forest managers' planning horizons in Germany and the Netherlands. Eur J For Res 128:1-11. doi:10. 1007/s10342-008-0234-6

IPCC (2007) Climate change 2007: impacts, adaptation and vulnerability. In: Parry ML, Canziani OF, Hanson CE (eds) Contribution of working group II to the fourth assessment report of the intergovernmental panel on climate change. Cambridge University Press, Cambridge

IPCC (2014) Summary for policymakers. In: Field CB, Barros VR, Dokken DJ, Mach KJ, Mastrandrea MD, Bilir TE, Chatterjee M, Ebi KL, Estrada YO, Genova RC, Girma B, Kissel ES, Levy AN, MacCracken S, Mastrandrea PR, White LL (eds) Climate change 2014: impacts, adaptation, and vulnerability. Part A: global and sectoral aspects. Contribution of Working Group II to the Fifth Assessment Report of the Intergovernmental Panel on Climate Change. Cambridge University Press, Cambridge, pp 1-32

Jones HP, Hole DG, Zavaleta ES (2012) Harnessing nature to help people adapt to climate change. Nat Clim Change 2:504-509. doi:10.1038/nclimate 1463

Lindner M, Maroschek M, Netherer S, Kremer A, Barbati A, GarciaGonzalo J, Seidl R, Delzon S, Corona P, Kolström M, Lexer MJ, Marchetti M (2010) Climate change impacts, adaptive capacity, and vulnerability of European forest ecosystems. For Ecol Manag 259:698-709. doi:10.1016/j.foreco.2009.09.023

McDaniels T, Mills T, Gregory R, Ohlson D (2012) Using expert judgments to explore robust alternatives for forest management under climate change. Risk Anal 32:2098-2112. doi:10.1111/j. 1539-6924.2012.01822.x

Morton TA, Rabinovich A, Marshall D, Bretschneider P (2011) The future that may (or may not) come: how framing changes responses to uncertainty in climate change communications. Glob Environ Change 21:103-109. doi:10.1016/j.gloenvcha. 2010.09.013

Moser SC, Ekstrom JA (2010) A framework to diagnose barriers to climate change adaptation. Proc Natl Acad Sci USA 107:22026-22031. doi:10.1073/pnas.1007887107

Murphy JM, Sexton DMH, Jenkins GJ, Booth BBB, Brown CC, Clark RT, Collins M, Harris GR, Kendon EJ, Betts RA, Brown SJ, Humphrey KA, McCarthy MP, McDonald RE, Stephens A,
Wallace C, Warren R, Wilby R (2009) UK climate projections science report: climate change projections. Met Office Hadley Centre, Exeter

Petr M, Boerboom L, Ray D, van der Veen A (2014a) An uncertainty assessment framework for forest planning adaptation to climate change. For Policy Econ 41:1-11. doi:10.1016/j.forpol.2013.12. 002

Petr M, Boerboom LGJ, van der Veen A, Ray D (2014b) A spatial and temporal drought risk assessment of three major tree species in Britain using probabilistic climate change projections. Clim Change 124:791-803. doi:10.1007/s10584-014-1122-3

Pidgeon N, Fischhoff B (2011) The role of social and decision sciences in communicating uncertain climate risks. Nat Clim Change 1:35-41. doi:10.1038/nclimate1080

R Development Core Team (2012) R: a language and environment for statistical computing

Sarkar D (2008) Lattice: multivariate data visualization with R, use R. Springer, Berlin

Schröter D, Cramer W, Leemans R, Prentice IC, Araújo MB, Arnell NW, Bondeau A, Bugmann H, Carter TR, Garcia CA, de la Vega-Leinert AC, Erhard M, Ewert F, Glendining M, House JI, Kankaanpää S, Klein RJT, Lavorel S, Lindner M, Metzger MJ, Meyer J, Mitchell TD, Reginster I, Rounsevell M, Sabaté S, Sitch S, Smith B, Smith J, Smith P, Sykes MT, Thonicke K, Thuiller W, Tuck G, Zaehle S, Zierl B (2005) Ecosystem service supply and vulnerability to global change in Europe. Science 310:1333-1337. doi:10.1126/science. 1115233

Tompkins EL, Few R, Brown K (2008) Scenario-based stakeholder engagement: incorporating stakeholders preferences into coastal planning for climate change. J Environ Manage 88:1580-1592. doi:10.1016/j.jenvman.2007.07.025

Tversky A, Kahneman D (1974) Judgement under uncertainty: heuristics and biases. Science 185:1124-1131. doi:10.1126/ science.185.4157.1124

Tversky A, Kahneman D (1981) The framing of decisions and the psychology of choice. Science 211:453-458. doi:10.1126/ science.7455683

Wickham H (2011) The split-apply-combine strategy for data. J Stat Softw 40:1-29 